\title{
SPEAKING ACTIVITIES IN MADRASAH IBTIDAIYAH: A META NARRATIVE ABOUT CHARACTER BUILDING AND MULTICULTURALISM POINT OF VIEW
}

\author{
Muqarramah Sulaiman Kurdi ${ }^{1}$, Hj. Mardiah ${ }^{2}$, Musyarrafah S. K ${ }^{3}$, \\ Muhammad Iqbal Ghazali Usman ${ }^{4}$, Taslimurrahman ${ }^{5}$
}

\author{
Universitas Islam Negeri Antasari Banjarmasin, Indonesia ${ }^{1,3}$, Sekolah Tinggi Ilmu \\ Tarbiyah Assunniyyah Tambarangan, Indonesia ${ }^{2,4,5}$ \\ E-mail: muqarramah@uin-antasari.ac.id ${ }^{1}$, yaakusya@gmail.com², \\ musyarrafah@uin-antasari.ac.id ${ }^{3}$, miqbalgu@gmail.com ${ }^{4}$,rahman021@gmail.com ${ }^{5}$
}

\section{DOI: $10.14421 /$ al-bidayah.v12i1.534}

\begin{abstract}
Teaching experience of speaking skills tends to be underestimated by the teacher. Because speaking, especially in Bahasa Indonesia, is considered as the mother tongue used in pupil's daily communication. In general, madrasas ibtidaiyah teachers assume that speaking skills in Bahasa Indonesia are not so essential compared to reading and writing. Speaking skills considered to be something that has been studied by pupils since birth at home so that speaking skills are not emphasized to be taught more on the primary level. When designing the learning process, the teacher only focuses on material and students' cognitive without paying attention to student skills in conveying the context or conversation. This study aims to develop a learning activities model of speaking with the content of character building and a multicultural perspective. The researchers applied the ASSURE model as the approach to developing the learning model. The findings of this study showed that the learning model is carried out by analyzing the characteristics of students, setting learning objectives, choosing media, learning methods, and teaching materials, utilizing teaching materials, involving students in learning activities, evaluating and revising learning programs. The content of character education and multiculturalism perspective are applied as teaching material.
\end{abstract}

Keywords: speaking activities; character building; multicultural education; ASSURE model; madrasah ibtidaiyah

\section{INTRODUCTION}

Speaking is a means of human communication. To be able to communicate, a person needs to grasp the intent to be communicated. ${ }^{1}$ In his book, Tarigan ${ }^{2}$ points out that speaking is a way of communicating. Speaking has a very close relationship with reading among the development of skills that the general ability of spoken language contributes to a background of beneficial experience and skills for teaching reading. ${ }^{3}$ The relationship with writing is indirect communication, not face to face, while speaking is

${ }^{1}$ Acep Hermawan, Metodologi Pembelajaran Bahasa Arab. Cet. 1. (Bandung: PT Remaja Rosdakarya, 2011), 136.

${ }^{2}$ Henry Guntur Tarigan, Berbicara sebagai suatu ketrampilan berbahasa, (Bandung: Angkasa, 2008), p. 4.

${ }^{3}$ Henry Guntur Tarigan, 8 . 
direct communication, face to face communication. Both writing and speaking, the mastering to these two abilities must pay attention to the same components, ${ }^{4}$ namely: (1) word structure/language, (2) vocabulary, (3) speed/general fluency, (4) the difference is that writing is related to orthography, (5) while speaking is related to phonology, (6) to be able to speak in a language properly, (7) the speaker must master the pronunciation, structure, and (8) vocabulary in question. ${ }^{5}$ Speaking is done as a habit in communication about various things in everyday life and is an essential element in success in all areas of life.

Based on the results of observations of researchers ${ }^{6}$ in several madrasah ibtidaiyah in Banjarmasin, most students who are in the madrasah ibtidaiyah still have difficulty in expressing their ideas in Indonesian, because they were not accustomed to training theirselves to talk in class. Based on interviews, it is known that many teachers in madrasah ibtidaiyah still do not provide opportunities for students to speak or express their ideas. According to the teacher, many students in classes are still shy and have low self-confidence to speak in front of their peers. The teacher asked the students to read in the classroom. This activity has caused many students who have difficulty speaking or express their opinions and ideas, resulting in the teaching process, becoming monotonous and increasingly complex. How students can have speaking skills if the students do not dare to express their speaking skills. Besides, the teacher teaches the student only fixated with textbooks, do not provide opportunities for students to practice. At present, there is still scarce literature that contains Indonesian language teaching models that emphasize aspects of speaking skills, ${ }^{7}$ especially in madrasah ibtidaiyah, especially sources that are practical and can be applied directly by the teacher. Although there have been many attempts that have been made by teachers to motivate students to improve students' speaking abilities.

\footnotetext{
${ }^{4}$ Henry Guntur Tarigan, 12.

${ }^{5}$ Burhan Nurgiyantoro, Teori Pengkajian Sastra. (Yogyakarta: Gadjah Mada University Press, 2007), 276.

${ }^{6}$ The author conduct preliminary-research on mid-July in 2019 in several schools in Banjarmasin. Researchers found out that not all students can speak Bahasa Indonesia well. The students have low selfconfidence and they are in dificulty when say some words in Bahasa Indonesia especially related to pronunciation, vowel, consonnant, and in uttering their ideas. These findings become the first step of researcher to gain many methods to help students and teacher hve several activities in speaking class.

${ }^{7}$ G. Suharto G. Suharto, "Pendidikan Bahasa Dalam Konteks Pendidikan Nasional,"Jurnal Cakrawala Pendidikan 3, no. 3 (1997), https://doi.org/10.21831/cp.v3i3.9107. See also Minto Rahayu, Bahasa Indonesia di Perguruan Tinggi. (Jakarta: Grasindo, 2007).
} 
Muqarramah Sulaiman Kurdi, Hj. Mardiah, Musyarrafah S. K, Muhammad Iqbal Ghazali Usman, Taslimurrahman

During this time, the experience of teaching Indonesian language speaking skills, especially in madrasah ibtidaiyah, tends to be underestimated by teachers because it is considered as the mother tongue used in students' daily communication. Generally, elementary/ madrasah ibtidaiyah teachers consider Indonesian language speaking skills to be less important than reading and writing paragraphs in Indonesian, and the material and teacher methods are also a challenge for madrasas in developing. ${ }^{8}$ Speaking skills are considered something that has been learned by students from birth, has been taught while at home, so speaking skills are not so emphasized to be taught further at the madrasah ibtidaiyah bench. Teachers can try various learning models, approaches, and learning strategies to help students improve their speaking abilities or skills. Several studies have shown various models and learning strategies that can be the choice of teachers in implementing in the classroom.

Based on the results of a study conducted by Dita Puspita Ekaningtyas, ${ }^{9}$ it is known that the socio-drama method used by the teacher in the learning process can improve students' speaking skills. According to the findings research of Hoiriyah \& Rachman ${ }^{10}$, they stated that learning models that can be used by teachers to improve children's ability to speak are speaking activities, such as: (1) role-playing, ${ }^{11}$ (2) talking stick, ${ }^{12}$ (3) Tagmen theory, ${ }^{13}$ (4) team games tournament, ${ }^{14}$ (5) project-based learning. ${ }^{15}$ These studies succeeded in proving that some model of learning was effective in improving students 'speaking skills. These studies also showed that students had a great

\footnotetext{
${ }^{8}$ Muqarramah Sulaiman Kurdi, "Madrasah Ibtidaiyah dalam Pandangan Dunia: Isu-Isu Kontemporer dan Tren dalam Pendidikan,” Al Ibtida: Jurnal Pendidikan Guru MI 5, no. 2 (October 31, 2018): 231-48, https://doi.org/10.24235/al.ibtida.snj.v5i2.3194.

${ }^{9}$ Dita Puspita Ekaningtyas, "Peningkatan Keterampilan Berbicara Menggunakan Metode Sosiodrama," Paedagogie 13, no. 2 (November 30, 2018): 71-76, https://doi.org/10.31603/paedagogie.v13i2.2368. See also Dwi Astuti Wahyu Nurhayati, "Using Local Drama in Writing and Speaking: EFL Learners' Creative Expression," Journal of English Language Teaching and Linguistics 1, no. 1 (April 17, 2016): 51-77, https://doi.org/10.21462/jeltl.v1i1.13.

${ }^{10}$ Khoiriyah Khoiriyah and Angraeny Unidia Rachman, "Bercakap-cakap sebagai Metode Peningkatan Kemampuan Berbicara Anak," JECCE (Journal of Early Childhood Care and Education) 2, no. 1 (March 17, 2019): 38-54, https://doi.org/10.26555/jecce.v2i1.567.

${ }^{11}$ Muhammad Muhyiddin, Ikha Ikha Listyarini, and Henry Januar Saputra, "Keefektifan Model Role Playing Berbantu Video Animasi Terhadap Kemampuan Berbicara Siswa Kelas V SD Negeri 01 Terban Kudus," Jurnal Basicedu 3, no. 2 (August 11, 2019): 564-71, https://doi.org/10.31004/basicedu.v3i2.40

${ }^{12}$ Yesi Handayani and Taufik Hidayat, "Model Talking Stick Dalam Pembelajaran Berbicara," Literasi : Jurnal Bahasa Dan Sastra Indonesia Serta Pembelajarannya 3, no. 1 (October 11, 2019): 41-50, https://doi.org/10.25157/literasi.v3i1.1997.

${ }^{13}$ Soeparno Soeparno, "Penerapan Teori Tagmemik' Dalam Pengajaran Bahasa Indonesia," Jurnal Cakrawala Pendidikan 1, no. 1 (1988), https://doi.org/10.21831/cp.v1i1.7437.

${ }^{14}$ Ratna Agustin, "Penerapan Model Pembelajaran Tipe Team Games Tournament (TGT) Untuk Meningkatkan Keterampilan Berbicara Siswa Kelas V SDN 2 Cerme Pace Nganjuk Tahun Pelajaran 2018," SASTRANESIA: Jurnal Program Studi Pendidikan Bahasa Dan Sastra Indonesia 6, no. 3 (October 1, 2019): 46-55, https://doi.org/10.32682/sastranesia.v6i3.1290.

${ }^{15}$ Susi Fitria, "Speaking Activities In Young Learners Classroom: The Implementation Of ProjectBased Learning Approach," Journal of English and Education 1, no. 2 (2013): 90-102, https://citeseerx.ist.psu.edu/viewdoc/download?doi=10.1.1.1011.9805\&rep=rep1\&type=pdf.
} 
opportunity to express themselves and their experiences optimally, where they were also required to involve all aspects of students' thoughts, emotions, physical, and experiences. These findings mean that the humanistic approach in the learning process is also prioritized. ${ }^{16}$ Teachers can also try conversation activities with the cooperative model techniques, where students in pairs have clattering conversation, and it is highly useful to use, both for students who are introverted or extroverted. These learning models certainly become the right choice for teachers in implementing the activity in the classroom that can improve students' ability to speak.

This study aims to provide an alternative learning model that can be used to improve students' speaking skills using the ASSURE approach. This approach was highlighted in the discussion because it became an example for teachers in using the ASSURE approach when developing other learning models. ${ }^{17}$ The ASSURE approach is one of the development models that is very easily applied by madrasah ibtidaiyah teachers in developing their learning design models, especially in developing learning models for speaking skills of students in madrasah ibtidaiyah. Furthermore, researchers include elements of character education and multicultural education content as teaching materials. The purpose was to adjust to the concept of education that is currently running in Indonesia and the context of Indonesia's pluralism. It is relevant with the government plan was currently working hard to build the personal dignity of the nation's children in the nuances of pluralism that is starting to erode by the many values of exclusivism, individualism, anarchism and transnational notions. Both issues, character education, and multicultural education concepts, are mainly used in the teaching-learning process.

\section{RESEARCH METHODS}

This study uses the approach to research and development, where the ASSURE mode $^{18}$ is used as the main tool in the development process of learning model design.

\footnotetext{
${ }^{16}$ Musyarrafah Sulaiman Kurdi, "Evaluasi Implementasi Desain Pendidikan Karakter Berbasis Pendekatan Humanistik," Elementary: Jurnal Ilmiah Pendidikan Dasar 4, no. 2 (November 27, 2018): 125-38, https://e-journal.metrouniv.ac.id/index.php/elementary/article/view/1243.

${ }^{17}$ James D. Russell and And Others, "Improving Technology Implementation in Grades 5-12 with the ASSURE Model,” T.H.E. Journal 21, no. 9 (1994): 66-70, https://eric.ed.gov/?id=EJ481965.

${ }^{18}$ The ASSURE model was developed by Heinich, Molenda, and Russell in the 1980s and according to researchers, this model is still very appropriate to be used in designing learning models. ASSURE consists of six components such as Analyze Learner (analyzing learning participants), State Objectives (formulating learning goals or competencies), Select methods, media, and materials (choosing methods, media and teaching materials), Utilizing media and materials (using media and materials teaching), Require learner participation (developing participants' participation), Evaluate and Revise (assess and
} 
Muqarramah Sulaiman Kurdi, Hj. Mardiah, Musyarrafah S. K, Muhammad Iqbal Ghazali Usman, Taslimurrahman

The ASSURE model emphasizes simplicity and ease of design in the application. ASSURE provides a large portion at the development stage that is systematic, effective, and able to develop a conducive classroom atmosphere. The ASSURE development model is very appropriate for researchers because it has the purpose of designing and planning the learning process. The learning model is carried out by analyzing the characteristics of students, setting learning objectives, choosing media, learning methods, and teaching materials, utilizing teaching materials, involving students in learning activities, evaluating, and revising learning programs.

\section{RESULT AND DISCUSSION}

\section{Speaking Activities for Improving Speaking Ability of Pupils in Madrasas Ibtidaiyah}

Speaking is the ability of students to say articulation sounds or express words to express, express, or convey thoughts, ideas, and feelings. Speaking is not just the pronunciation of sounds or words, but as mentioned by Tarigan, speaking as a tool to communicate ideas that are arranged and developed according to the needs of the listener or listener. Speaking as a communication tool requires the speaker to be able to convey his thoughts effectively. Then, the speaker has to understand the meaning of everything that will be discussed or communicated. The speaker also can be able to evaluate the effects of the conversation on the listener and know the basic principles of the conversation situation both individually and in general.

The teacher in the class trains students' speaking skills in diverse ways, such as training students in diverse ways. One of the activities in speaking that is often exemplified is to open his mouth full, in a loud high voice, and actually, this activity is not very recommended by ancient parents, ${ }^{19}$ thus bringing up a code of ethics in speaking.

improve).Heinich, R.J, Molenda, M., Russell, JD, \& Smaldino, SE. (2005). Instructional Technology and Media for Learning. New Jersey, Columbus. Multi-Media Pembelajaran. See also Ahmad Abdullahi Ibrahim, "Comparative Analysis Between System Approach, Kemp, And ASSURE Instructional Design Models," International Journal of Education and Research 3, no. 12 (2015): 261-70, http://www.ijern.com/journal/2015/December-2015/20.pdf.

${ }^{19}$ Principle in speaking: (a) The process of speaking requires at least two people; (b) Use a linguistic password that is understood together; (c) Accept or acknowledge a common reference area; (d) An exchange took place between the speaker and the listener; (e) Two-way reciprocity between the speaker and the listener. (f) Relating to the present; (g) Involving language/vocals and hearing/auditory of course in speaking activities there will be vowels that are issued and heard, such as speaking in class, at home, at work, and on the telephone, this is the most original conversation. But it does not happen if the activity is in the form of mime and pictures; (h) Making everything tangible and acceptable as proof/evidence. R. Kunjana Rahardi, Bahasa Kaya, Bahasa Berwibawa: Bahasa Indonesia Dalam Dinamika Konteks 
Talking activities are activities that are productive after listening activities are carried out. The purpose of speaking lessons, in general, is to be able to use language verbally. Speaking activities include activities: telling stories, discussing, asking questions, giving speeches, making reports (oral), and others. The teacher can organize the speaking activities for first-grade students who are just starting to learn a second language, in the form of answering teacher questions with short answers such as: yes, no, I, have not, already, and others. ${ }^{20}$ According to Broto ${ }^{21}$, certain conditions can be stated to create effective speaking activities. The teacher, while teaching and practice the students' speaking ability in madrasah should have known the general principle in speech so that the learning process is fundamental and its philosophy. As for some general principles ${ }^{22}$ in speaking based on Brooks opinion ${ }^{23}$ shows in Figure 1.

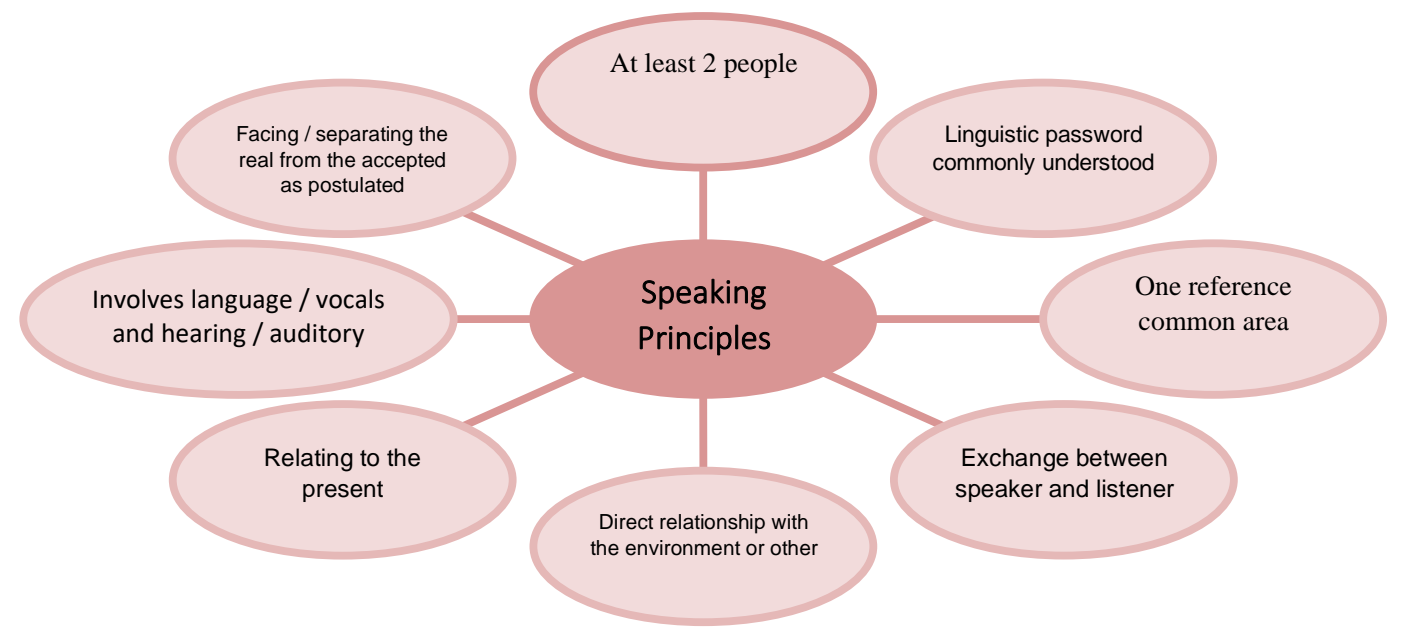

Figure 1

Brooks Theory of Speaking Principles

Ekstrabahasa. (Jakarta: Andi Offset, 2006), 66. See also R. Kunjana Rahardi, Dimensi-Dimensi Kebahasaan: Aneka Masalah Bahasa Indonesia Terkini.. (Jakarta: Erlangga, 2006).

${ }^{20}$ A. S. Broto, Pengajaran Bahasa Indonesia sebagai Bahasa kedua di SD Berdasarkan Pendekatan Linguistik Kontrastif (Jakarta: Bulan Bintang, 1980), 102. See also A. S. Broto, Metodologi Proses Belajar Mengajar Bahasa Indonesia (Sala: Tiga Serangkai 1982)..

${ }^{21}$ Certain conditions: they are: (a) Terms of speech (b) Terms of the song; the sentence song should be clear and following the function of the word or language. (c) Physical requirements; physical gestures. A. S. Broto, Pengajaran Bahasa Indonesia, 103

${ }^{22}$ Henry Guntur Tarigan, 16.

${ }^{23}$ Brooks, W. T. High Impact Public Speaking. (New Jersey: Prentice Hall Direct, 1988), 30-31. These principles should be known by madrasa teachers so that when developing students' speaking abilities, learning will become more real and students' speaking abilities will be implemented in real life by communicating with people around them properly and appropriately. See also Marlina Eliyanti Simbolon, S. S. Tuturan dalam Pembelajaran Berbicara Dengan Metode Reciprocal Teaching. (Jakarta: Media Sahabat Cendekia, 2019); See also Nurbiana Dhieni et al., PAUD4106 - Metode Pengembangan Bahasa (Tangerang Selatan: Universitas Terbuka, 2014). 
Muqarramah Sulaiman Kurdi, Hj. Mardiah, Musyarrafah S. K, Muhammad Iqbal Ghazali Usman, Taslimurrahman

Figure 2 illustrates the Wolbert theory.

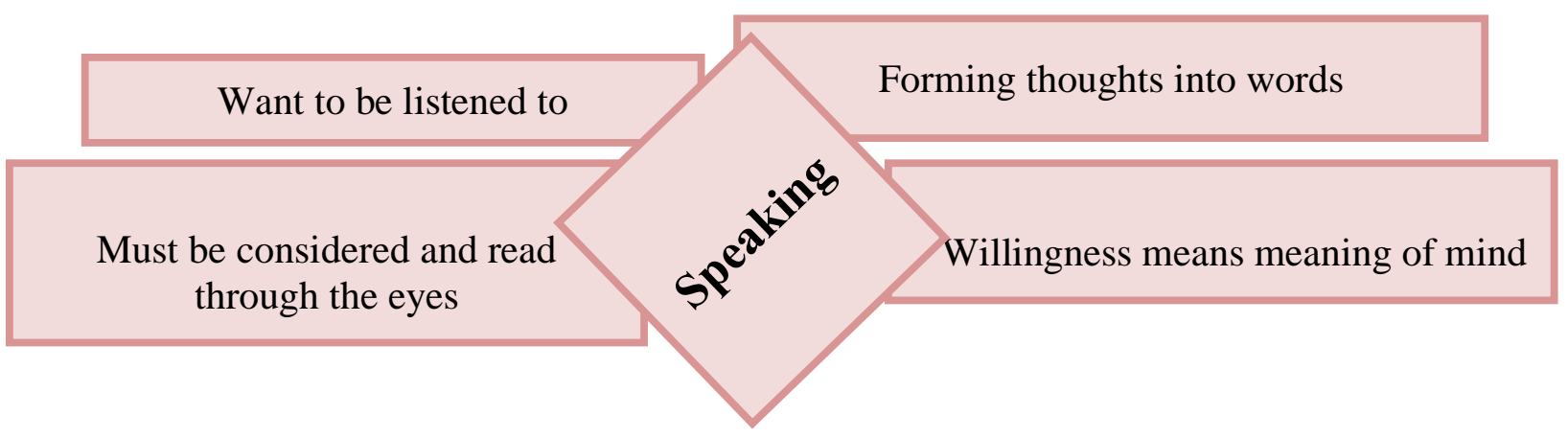

Figure 2

Brooks Theory of Speaking

Unlike Brooks, Wolbert ${ }^{24}$ analyzes that there are at least four issues that occur in the process of speaking, namely: (1) Speaking has a purpose and purpose, the meaning possessed by the listener of the will of the speaker himself, which is the thought. (2) The speaker is a language user, shapes his thoughts and feelings into words. (3) The lawyer is something he wants to hear, conveying his intentions and words to people through sound. (4) The speaker is something that must be seen, shows appearance or an action that must be considered and read through the eyes. No exception is the person who communicates by telephone.

\section{Strengthening Character Education in Primary School}

Implementation of character education in schools is not a separate subject, nor is it an additional standard, such as the core of the competency (KI) and basic competence (KD). Character education can be integrated into existing subjects, self-development, and school culture, as well as local content. ${ }^{25}$ Character education, especially in elementary

${ }^{24}$ See this theory in Henry Guntur Tarigan, 16. That is the theory of the nature of speaking by Wollbert, which certainly would support a teacher to create student speaking activities which will generate listener and speaker in more effective communication.

${ }^{25}$ Sri Judiani, "Implementasi Pendidikan Karakter di Sekolah Dasar Melalui Penguatan Pelaksanaan Kurikulum," Jurnal Pendidikan dan Kebudayaan 16, no. 9 (October 10, 2010): 280-89, https://doi.org/10.24832/jpnk.v16i9.519. See also Bambang Dalyono and Enny Dwi Lestariningsih, "Implementasi Penguatan Pendidikan Karakter Di Sekolah," Bangun Rekaprima: Majalah Ilmiah Pengembangan Rekayasa, Sosial Dan Humaniora 3, no. 2, Oktober (October 11, 2016): 33-42, https://doi.org/10.32497/bangunrekaprima.v3i2. See also Ma'arif, Muhammad Ahyar, and Abdul Hamid. "Pendidikan Karakter Berbasis Pendidika Islam." An-Nisa' 11, no. 1 (February 6, 2019). https://doi.org/10.35719/ansa.v11i1.759. See also Purniadi Putra, "Pendidikan Karakter Berbasis Etnopedagogi Di Madrasah Ibtidaiyah Negeri Kabupaten Sambas Kalimantan Barat" (Disertasi, Banjarmasin, Universitas Islam Negeri (UIN) Antasari Banjarmasin, 2019), http://idr.uinantasari.ac.id/11242/. 
school, is one of the popular issues among educators and researchers in Indonesia. ${ }^{26}$ The Ministry of Education and Culture on July 17, 2017, to provide information on its website related to the development of character education in Indonesia. It was stated that since Indonesia under President Joko Widodo and Jusuf Kalla, the Strengthening of Character Education $^{27}$ as an entry point for reforming national education and strengthening character has become one of the government's priority programs in the field of education.

Strengthening the Characters Education Program focuses not only on literacy or if the thought, but it also encourages attention, though as if the ethical and spiritual and aesthetic sense as in the implementation of national education. Also, it supports sports, such as kinesthetic, that also be one part of the education program. These four dimensions are implemented and implemented in education programs in a comprehensive manner, continuous and simultaneous. ${ }^{28}$ The integration of Strengthening Character Education (IoSCE) not only through the process of extracurricular learning. The implementation of the IoSCE also through curricular, and extracurricular activities organized by schools. Strengthening Character Education is held based on school culture development and collaboration with communities that exist outside the school environment.

In Strengthening Education Character, it has been downsized from 18 values to 5 main character values whose source is Pancasila. These 5 values are priority values in the Strengthening Character Education movement, including religious values, nationalism, integrity, independence, and cooperation. ${ }^{29}$

\footnotetext{
${ }^{26}$ Ngadiyono Ngadiyono and Sukidjo Sukidjo, "Implementasi Pendidikan Karakter Di Madrasah Ibtidaiyah," Harmoni Sosial: Jurnal Pendidikan IPS 6, no. 1 (March 24, 2019): 86-99, https://doi.org/10.21831/hsjpi.v6i1.15397 See also Ma'arif, Muhammad Ahyar, and Abdul Hamid. "Pendidikan Karakter Berbasis Pendidika Islam." An-Nisa' 11, no. 1 (February 6, 2019). https://doi.org/10.35719/ansa.v11i1.759. See also Ayu Dewi Citra Anggraini, Ika Ratih Sulistiani, and Devi Wahyu Ertanti, "Strategi Pembelajaran Akidah Akhlak Di MI Sunan Kalijogo Karangbesuki Malang," JPMI: Jurnal Pendidikan Madrasah Ibtidaiyah 1, no. 2 (July 15, 2019): 44-51, http://riset.unisma.ac.id/index.php/JPMI/article/view/3102. See also Nita Karmila and Rini Sri Indriani, "Nilai-Nilai Pendidikan Karakter Pada Materi Ajar Pendidikan Lingkungan Hidup Untuk Sekolah Dasar/ Madrasah Ibtidaiyah Kelas II," Jurnal Pendidikan Dan Pengajaran Guru Sekolah Dasar (JPPGuseda) 2, no. 1 (March 11, 2019): 26-29, https://doi.org/10.33751/jppguseda.v2i1.991.

${ }^{27}$ Ministry of Education and Culture (MOEC), Kebijakan Penguatan Pendidikan karakter, Penguatan Pendidikan Karakter, tujuan PPK, Accessed on 19 July 2019, https://cerdasberkarakter.kemdikbud.go.id/tentang-ppk/.

${ }^{28}$ Ministry of Education and Culture (MOEC)

${ }^{29}$ Ministry of Education and Culture (MOEC); Each value grows mutual integration of each other, not separated respectively, it interacts and improves dynamically. The purpose of strengthening character education is to build and equip students as the golden generation of Indonesia in 2045 to face the dynamics of change in the future. Also, to develop a national education platform that places character education as the main soul by taking into account the diversity of Indonesian culture, and revitalizing and strengthening the potential and competence of the education ecosystem.
} 
Muqarramah Sulaiman Kurdi, Hj. Mardiah, Musyarrafah S. K, Muhammad Iqbal Ghazali Usman, Taslimurrahman

\section{Multicultural Education as an Approach Progressive in Speaking Learning Process}

The diversity that exists in Indonesia requires an educational concept that can provide opportunities for every student to have the opportunity through education without any discrimination caused by their different backgrounds, such as religion, culture, language, and different ethnicities. The purpose of education must be uniformity for all components of education in Indonesia, namely towards a society that is cultured, just, prosperous, and prosperous without restrictions on diversity in society. ${ }^{30}$ Therefore, in the education process, the concept of multicultural education cannot be released in the learning process. According to some researchers in Indonesia, multicultural education is mainly applied in the learning process. ${ }^{31}$ In its implementation, the multicultural education process aims to give appreciation to each individual for their uniqueness. The learning process is expected to be able to reward diversity. Every student gets the same rights and carries out the same obligations without the influence of the difference itself. The learning process needs to be designed on a multicultural basis so that teachers' and students' perceptions about the meaning of pluralism in Indonesia can become multicultural-based attitudes and behaviors. In the end, the learning process can be a place to foster multicultural attitudes of people in Indonesia.

Multicultural education is considered as one of the progressive approaches, where multicultural education can provide ideas to correct weaknesses in the existing education process, where the value of discrimination grows. Holistically, multicultural education

${ }^{30}$ Dede Rosyada, “Pendidikan Multikultural Di Indonesia Sebuah Pandangan Konsepsional, ” SosioDidaktika: Social Science Education Journal 1, no. 1 (June 29, 2014): 1-12, https://doi.org/10.15408/sd.v1i1.1200. See also Zakiyuddin Baidhawy, Pendidikan Agama Berwawasan Multikultural (Jakarta : Erlangga, 2005).

31 Erlan Muliadi, "Urgensi Pembelajaran Pendidikan Agama Islam Berbasis Multikultural Di Sekolah,” Jurnal Pendidikan Islam 1, no. 1 (2012): 55-68, https://doi.org/10.14421/jpi.2011.11.55-68. See also Syafruddin Syafruddin, Masyhuri Masyhuri, and Suud Suud, "Urgensi Pendidikan Multikultural Untuk Mencegah Faham Radikalisme Pada Siswa SMA Dan MA Di Kecamatan Dompu," Jurnal Pendidikan Dan Pengabdian Masyarakat 2, no. $1 \quad$ (January $23, \quad$ 2019), https://jurnalfkip.unram.ac.id/index.php/JPPM/article/view/1009. See also Vera Yuli Erviana and Laila Fatmawati, "Urgensi Pendidikan Multikultural Sebagai Wadah Strategis Untuk Menanamkan Karakter Toleransi Di Sekolah Dasar," Proceeding of The URECOL, January 21, 2019, 297-302, http://repository.urecol.org/index.php/proceeding/article/view/446. See also Hasan Baharun and Robiatul Awwaliyah, "Pendidikan Multikultural Dalam Menanggulangi Narasi Islamisme Di Indonesia," Jurnal Pendidikan Agama Islam (Journal of Islamic Education Studies) 5, no. 2 (November 2, 2017): 224-43, https://doi.org/10.15642/jpai.2017.5.2.224-243. 
can motivate educational institutions to develop policies that are friendly about diversity, able to foster awareness of diversity in society, such as strengthening the value of tolerance, sympathy, empathy, help, and tolerance. These values are easily developed in schools as a result of engineering education in instilling an awareness of multicultural values. In the end, all students and teachers become the door to the formation of societies multicultural, accustomed to being positive in diversity and differences. The practice of multicultural education can be done in a variety of ways that are varied, flexible and integrative in all components of the learning process that exists in schools and all school extracurricular activities. Arifin points out that there are at least five dimensions in the implementation of multicultural education ${ }^{32}$, such as the dimensions of equal pedagogy, school culture, empowering school structures, the process of compiling knowledge, and content integration.

In essence, multicultural education requires the creation of individuals who value differences, avoid the seeds of potential divisions in an uncontrolled context, respect democracy, the independence of each individual, and equality. Besides, multicultural education also requires an agreement on diversity. The learning process that is designed based on multicultural education treats every student with the principle of democracy; every child has the same opportunity to achieve learning goals. Each student can appreciate the different ethnic groups, genders, and understanding religious that each person has. Each student is also expected to be able to appreciate the people around him who have different cultures and dialects. This explanation means that multicultural education is the bond of national unity. According to Amirin ${ }^{33}$ multicultural education can make cultural values as an element of pluralism recognition to students.

The teacher can organize the creative teaching and learning process to produce a learning process, especially in improving effective speaking skills. In this study, the authors propose a learning system design model proposed by Sharon E, Smaldino, James

\footnotetext{
${ }^{32}$ Arifin, Ahmad Hidayatullah. Implementasi Pendidikan Multikulutral dalam Praksis Pendidikan di Indonesia. Jurnal Pembangunan Pendidikan: Fondasi dan Aplikasi, 1, no. 1 (June, 2012): 72-82. https://doi.org/10.21831/jppfa.v1i1.1052

${ }^{33}$ Tatang. M. Amirin, Implementasi pendekatan pendidikan multikultural kontekstual berbasis kearifan lokal di Indonesia. Jurnal pembangunan pendidikan: Fondasi dan aplikasi, 1, no. 1, (June, 2012): 1-16. https://doi.org/10.21831/jppfa.v1i1.1047
} 
Muqarramah Sulaiman Kurdi, Hj. Mardiah, Musyarrafah S. K, Muhammad Iqbal Ghazali Usman, Taslimurrahman

D. Russel, Robert Heinich, and Michael Molenda, namely the ASSURE model. ${ }^{34}$ based on character education and multicultural education. The purpose of using this ASSURE model in the teaching and learning process of speaking skills is to create effective and efficient learning activities where values in character education and multicultural education become the main ingredients in development, which will use media and technology. The ASSURE model is more focused on planning learning for use in actual situations of learning Indonesian speaking skills in class. The advantages of the ASSURE learning model are that it is simpler because it is implemented on the system learning on a smaller scale. Gagne points out that good learning design must be able to trigger the motivation of students to follow the lesson. ${ }^{35}$ This motivational step is then followed by a series of systematic learning processes, assessment of learning outcomes, and providing feedback on achieving learning outcomes on an ongoing basis.

Learning outcomes assessment needs to be designed so that it can measure students' speaking skills. Besides, students need to obtain feedback in the form of knowledge about learning outcomes, such as linguistic factors as supporting effectiveness in speaking. The aims are to motivate students to hone their speaking skills or the learning process more effectively and efficiently. The implementation of this activity is after going through the process of assessing learning outcomes.

\section{The First Stage, Analyze Learners}

The first step that needs to be taken in applying the ASSURE model in learning speaking skills with the content of character education and multicultural education is to identify the characteristics of students who will be doing learning activities. The teacher can ask several questions to help analyze students, such as (1) Who are the students who will undertake the teaching and learning process of speaking skills with the content of character education and multicultural education?; (2) What are the general characteristics of students who will undertake to teach and to learn speaking skills with the content of character education and multicultural education?; (3) What specific components of

${ }^{34}$ Sharon E Smaldino, Deborah L Lowther, Clif Mims, James D Russell. Instructional Technology and Media for Learning. (Upper Saddle River, N.J. : Pearson/Merrill/Prentice Hall, 2005); See also Benny A. Pribadi. Model Desain Sistem Pembelajaran. (Jakarta: Dian Rakyat, 2009)

${ }^{35}$ Benny, A. P. Model Desain Sistem Pembelajaran, 111. See also Muqarramah Muqarrahmah, "Student Centered Learning Approaches; Learning Design Aqidah Morals For Government Elementary School," Tarbiyah: Jurnal Ilmiah Kependidikan 5, no. 2 (February 7, 2017), https://doi.org/10.18592/tarbiyah.v5i2.982. 
speaking skills do students have that will undertake the teaching and learning process of speaking skills with the content of character education and multicultural education?; (4) What is the learning style of students who will do the teaching and learning process of speaking skills with the content of ch4racter education and multicultural education?

Analysis of the characteristics of students in the form of this question is very important because it will greatly help students in efforts to achieve learning objectives. The analysis step consists of two stages, namely performance analysis or performance analysis and needs analysis. ${ }^{36}$ First, the teacher tries to find out and clarify whether the performance problems encountered require a solution in the form of organizing speaking skills learning program with the contents of character education and multicultural education or management improvement. Examples of performance that require solutions in the form of program implementation are, students' basic skills and knowledge about speaking in front of others are very low; this causes low student performance in honing the ability to speak in front of others. Therefore, the teacher seeks to develop solutions in the form of organizing speaking skills development programs, such as holding training programs for reading speeches, poetry, and class dramas with the values of character education and multicultural education.

The second is the needs analysis. Here the teacher determines speaking abilities or skills what students need to learn to improve their speaking ability or a learning achievement. There are two major issues used in analyzing these needs, such as do students need predetermined learning goals? Are students able to achieve the specified learning goals? Furthermore, if the information from these two questions has been answered and leads to learning as a solution, then the teacher needs to do a needs analysis by answering a few more questions, ${ }^{37}$ namely: (a) What are the characteristics of students who will take part in a learning program for speaking skills with content character education and multicultural education?; (b) What knowledge and skills do students have in speaking with the content of character education and multicultural education?; (c) What indicators or criteria are used to determine that students have achieved predetermined competencies after carrying out the learning process with the contents of character education and multicultural education?; (d) What conditions do students need to be able

\footnotetext{
${ }^{36}$ Benny A. Pribadi. Model Desain Sistem Pembelajaran, 128.

${ }^{37}$ Benny A. Pribadi, 129.
} 
Muqarramah Sulaiman Kurdi, Hj. Mardiah, Musyarrafah S. K, Muhammad Iqbal Ghazali Usman, Taslimurrahman

to demonstrate the speaking competence they have trained with the content of character education and multicultural education?; (e) What abilities and competencies do students need to have to improve their ability to speak with the content of character education and multicultural education?

\section{The Second Stage, State Objectives}

The next step in the ASSURE learning system design model is to set more specific learning goals. The purpose of learning speaking skills in subjects with character education and multicultural education content can usually be obtained from the syllabus or curriculum, information recorded in textbooks, or formulated the teacher himself. The purpose of this learning is a statement that describes the speaking skills obtained by students after taking the learning process. In this design, the aim is to emphasize aspects of developing the values of students 'character formation and students' understanding of diversity. This step means a statement that describes the competencies that need to be mastered by students and describes the conditions needed by students to show the learning outcomes achieved and the level of mastery of students or degree of speaking skills learned. In designing the learning program at this stage, the teacher must look for questions on several key questions, such as (1) Speaking skills in what specific sections should students have after completing the learning program with the contents of character education and multicultural education?; (2) What indicators can be used to measure students' success in participating in the learning process of speaking skills with the content of character education and multicultural education?

\section{The Third Stage, Select Methods, Media, And Materials}

The next step is to choose the methods, media, and teaching materials that will be used in the process of learning speaking skills with the content of character education and multicultural education. The selection of methods, media, and appropriate teaching materials will be able to optimize student learning outcomes and assist students in achieving the competencies set in the learning objectives of speaking skills with the content of character education and multicultural education. In choosing the methods, media, and teaching materials to be used, several options can be made, namely choosing existing media and materials teaching, modifying existing teaching materials, and 
producing new teaching materials for reading skills. The teacher also leads the learning experience ${ }^{38}$ that students need to have while participating in learning activities. In designing the learning program at this stage, the teacher looks for questions on several key questions, such as: (1) What equipment or conditions are needed by students to be able to demonstrate speaking skills with the content of character education and multicultural education?; (2) What Indonesian teaching materials and activities can be used to support speaking skills learning programs with content on character education and multicultural education?

Table 1

Content Material

Values of Character Education and Multicultural Education

\begin{tabular}{|c|c|c|}
\hline \multicolumn{3}{|c|}{ Content Learning Materials Speaking Skills } \\
\hline & Multicultural Education & Character Education \\
\hline Value 1 & Substantive & Religious \\
\hline Value 2 & $\begin{array}{l}\text { Mutuality (understanding, respect, } \\
\text { trust) }\end{array}$ & Honest \\
\hline Value 3 & Tolerance to differences & Tolerance \\
\hline Value 4 & Pluralism & Discipline \\
\hline Value5 & Diligent & Hard Work \\
\hline Value 6 & Hard Work & Creative \\
\hline Value 7 & Inclusivism & Independent \\
\hline Value 8 & Skill-ful & Democratic \\
\hline Value 9 & Knowledgeable; open minded & Curiosity \\
\hline Value 10 & Consistency & Spirit of nationality \\
\hline Value 11 & Global relations & Love the motherland \\
\hline Value 12 & Unity & Appreciate the achievement \\
\hline Value 13 & Civilized & Friendly / communicative \\
\hline Value 14 & Educated; Love to study & Peace-loving \\
\hline Value 15 & Humanist & Reading \\
\hline value 16 & Moral & Concern for the environment \\
\hline Value 17 & Humble & Social care \\
\hline Value 18 & Moderate & Responsibility \\
\hline
\end{tabular}

${ }^{38}$ Barbara Trudell and Benjamin Piper, "Whatever the Law Says: Language Policy Implementation and Early-Grade Literacy Achievement in Kenya," Current Issues in Language Planning 15, no. 1 (January 2, 2014): 4-21, https://doi.org/10.1080/14664208.2013.856985. 
Muqarramah Sulaiman Kurdi, Hj. Mardiah, Musyarrafah S. K, Muhammad Iqbal Ghazali Usman, Taslimurrahman

After the design, the next step is the development in the implementation of the learning system model, which includes the activities of selecting and determining appropriate methods, media, and learning strategies to be utilized in delivering the material or substance of the learning program. ${ }^{39}$ In development there are two things that need to be achieved, namely: (1) Producing, buying, or revising teaching materials that will be employed to achieve the learning goals that have been previously formulated, teaching materials used with the content of character education and multicultural education. (2) Choose the best media or media combination that will be used to achieve the goal of learning speaking skills with the content of character education and multicultural education.

\section{The Fourth Stage, Utilize Materials}

The next steps to be done after h choosing methods, media, and teaching materials is to use them in speaking skills activities. Before using methods, media, and teaching materials, the teacher first conducts trials to ensure that the three components can function effectively for use in real situations/settings.

The next step is to prepare the classes and supporting facilities needed to be able to use the methods, media, and selected materials teaching. All three components can be used if everything is ready. The form of realization of design and development was in the form of delivery of learning material from the teacher to students. The main goals of which are: (1) to guide them to achieve learning goals or speaking skills competencies, (2) ensure the provision of solutions to overcome the learning outcomes gap faced by students, (3) ensure that all of the students got feedback at the end of the learning program, and (4) students need to have the ability in terms of speaking skills with the content of character education and multicultural education. Therefore, in the implementation, the teacher has to know the learning methods that are relevant to the learning material type. The teacher also has to understand what efforts or strategies can be made to attract

${ }^{39}$ Benny A. Pribadi. Model Desain Sistem Pembelajaran, 114. See also Musyarafah, Musyarafah. "Development of English Teaching Materials Charged Based Character Education using Interactive Multimedia Macromediaflash (Case Study Course Learning English Teacher Education Department Madrasah)." Tarbiyah: Jurnal Ilmiah Kependidikan 5, no. 2 (2017): 44-60. http://dx.doi.org/10.18592/tarbiyah.v5i2.983. See also Umar Fauzan, "Developing EFL Speaking Materials for the Second Semester Students of STAIN Samarinda" (Proceedings of 61th TEFLIN International Conference, Surakarta, Jawa Tengah: Universitas Sebelas Maret, 2014), 861-64, https://core.ac.uk/reader/43024740. 
students' interests to remain able to focus attention on the delivery of the material or substance of learning speaking skills with the content of character education and multicultural education to be delivered.

\section{The Fifth Stage: Require Learner's Participants}

Provision of training for pupils to speak, ${ }^{40}$ it is one way to involve students' mental activities with the material or substance of the material being studied, namely material with the content of character education and multicultural education. Students who are actively involved in learning activities will quickly follow and learn the learning material in speaking skills. After students participate actively in the learning process, providing feedback in the form of knowledge about learning outcomes will motivate students to achieve higher learning achievements in speaking skills.

\section{The Sixth Stage: Evaluate and Revise}

Next, in the evaluation stage, ${ }^{41}$ conduct an assessment of the effectiveness of learning and also student learning outcomes in speaking skills. The process of evaluating the continuous set of learning speaking skills needs to be carried out to gain a comprehensive picture of the quality of a learning program. Several questions can help in the evaluation process, such as: (a) Is the goal of learning speaking abilities with the content of character education and students can achieve multicultural education?; (b) Does the process of learning speaking skills with the content of character education and multicultural education in the presence of methods, media and learning strategies used can train students' speaking skills?; (c) Are students actively involved in the learning process of speaking skills with the content of character education and multicultural education being learned?

In this study, the writer has a key in developing; that is, if the results in this evaluation process show unsatisfactory results, then the learning model designer needs to revise the model. The ASSURE model is a learning and practical system model and easy to implement to design learning models, both individual and classical. All the steps used in the ASSURE model are used to develop effective, efficient and interesting learning

\footnotetext{
${ }^{40}$ Benny A. Pribadi. Model Desain Sistem Pembelajaran, 117. See also Florence Stevens, “Activities to Promote Learning and Communication in the Second Language Classroom," TESOL Quarterly 17, no. 2 (1983): 259-72, https://doi.org/10.2307/3586653.

${ }^{41}$ Benny A. Pribadi. Model Desain Sistem Pembelajaran, 117.
} 
Muqarramah Sulaiman Kurdi, Hj. Mardiah, Musyarrafah S. K, Muhammad Iqbal Ghazali Usman, Taslimurrahman

activities, and to ensure the quality of learning speaking skills with the content of character education and multicultural education created.

Next, the teacher evaluates, which is a process carried out to provide value to the learning skills speaking program. However, the evaluation can be carried out during the implementation of ASSURE steps, for example at the time of analysis, the evaluation process is carried out by clarifying the ability in speaking skills that must be possessed by students after participating in learning speaking skills with the content of character education and multicultural education. This evaluation is considered a formative evaluation.

Evaluation can, besides, be completed by comparing the learning outcomes achieved by students with the objectives to be formulated. The evaluation aims to know students' attitudes towards learning activities as a whole. The other aim is to find out an increase in students' speaking skills which represent an impact of participation in a speaking skills learning program. The last, the goal of learning program evaluation is to find out the benefits felt by schools due to an increase in students' speaking skills after participating in activities learning.

In evaluating teachers should know whether students like the learning program they are taking, how much benefit is felt by students in participating learning programs, how far students can practice their skills speaking, how many students can demonstrate the skills they have learned, and how much the program contributes learning carried out on student achievement. Thus, the implementation of the ASSURE learning design model in subjects especially speaking skills with a content of character education and multicultural education carried out systematically, is expected to support teachers to create effective, efficient, and exciting learning.

The essential point is whatever the model used by the teacher in designing learning about speaking skills with a content of character education and multicultural education, the form of teaching must be student-centered. Then, the teaching has orientation to indicators that students want to master, learning is collaborative, emphasize aspects of skills, process-oriented, high-level thinking, emphasizing practice, life skills, group training that means taking place in the community, and formative assessment. All of these processes are expected to be beneficial for students' lives in the community. 
There are two characteristics of the process of teaching aspects of speaking skills, which are controlled; content and type of discourse are determined and restricted, and are free; depends on the desires and creativity of students. As for teaching speaking, according to Djiwandono, the teacher should prioritize the content and meaning of the verbal messages conveyed by students. ${ }^{42}$ Various forms of exercises and techniques can be done to improve students 'speaking skills with varying degrees of difficulty according to the level of students' abilities.

\section{Teachers' Ways to Improve the Speaking Ability of Madrasas Ibtidaiyah's Students with Character Education and Multicultural Education}

In practicing elementary school pupils' speaking skills, there are also many techniques and approaches that teachers may be able to use. ${ }^{43}$ Several activities are: the first is pronouncement exercises; for students in lower classes such as classes 1 and 2, the teacher can ask students to do pronunciation exercises vocal a, i, u, e. and o. The teacher trains students by using a variety of vocabulary that uses vowels in open and closed tribes. For example, the words are religion, wisdom, cultural customs, etiquette, trustworthy, fair, knowledgeable, beautiful, age, age, empathy, people, sports, optimism, and others. This exercise can foster and develop students' creative values.

The second is the memorization of drama dialogue. This technique is an exercise in imitating and memorizing dialogues about various situations and opportunities ${ }^{44}$, for example, related to the diversity and diversity of Indonesia. Through training, these students are expected to be able to achieve good proficiency in conversations conducted naturally and not fabricated in good and correct Indonesian. Although it may initially be

\footnotetext{
${ }^{42}$ Soenardi Djiwandono, Tes Bahasa dalam Pengajaran, (Bandung: Penerbit ITB, 1996), the teacher should prioritize the content and meaning of the verbal messages conveyed by students.

${ }^{43}$ Acep Hermawan, Metodologi Pembelajaran Bahasa Arab. Cet. 1. (Bandung: PT Remaja Rosdakarya, 2011), 14; See also Bambang Sugeng, "A Learning Strategy Profile of Indonesian Elementary School Students," RELC Journal 28, no. 2 (December 1, 1997): 82-106, https://doi.org/10.1177/003368829702800205. See also Maidar G. Arsjad and Mukti. U.S., Pembinaan Kemampuan Berbicara Bahasa Indonesia, (Jakarta : Erlangga, 1988). pronunciation exercises, memorizing drama dialogues, dialogue through pictures, dialogues guided, gesture, techniques practice pattern, group conversations, role-playing, social expression training, field practice, speeches, fairy tales, stories, rhymes, poems, descriptions of events or objects around, and discussions. See also Dita Puspita Ekaningtyas, "Peningkatan Keterampilan Berbicara Menggunakan Metode Sosiodrama," Paedagogie 13, no. 2 (November 30, 2018): 71-76, https://doi.org/10.31603/paedagogie.v13i2.2368.

${ }^{44}$ Student A: Where are you from?; Student B: I come from Kalimantan; Student A: What is your tribe?; Student B: I have Dayak ethnicity; Student A: Do you love your country?; Student B: Yes, I love Indonesia.
} 
Muqarramah Sulaiman Kurdi, Hj. Mardiah, Musyarrafah S. K, Muhammad Iqbal Ghazali Usman, Taslimurrahman

patterned based on memorization, if students are asked to always do the exercises continuously then over time it will enhance the ability to communicate naturally and smoothly.

The third is dialogue through pictures. This technique is given so that students can understand facts through images that are orally expressed according to their level. This engaging dialogue ${ }^{45}$ can sufficiently develop cultural values Knowing local social relations, intellectual curiosity, social care, social tolerance of differences and the values of character education and other multicultural education. In this case, the teacher makes preparations in the form of preparing drawings relating to various professions, morals, morals, habits, or even a person's behavior, and showing one by one to students while asking questions, then students answer according to the picture shown. Questions can be developed to train students' speed of thinking and communication skills, while students are also accustomed to utter sentences.

The fourth is dialog guided. This technique is given so that students are able to complete the conversation under the particular situation being trained. In this case the teacher only gives examples of questions and answers, for example, about activities that will be carried out while on vacation and visiting places of worship. The teacher gives an example of how to answer is presented in this question and answer activities. Then, the teacher provides a sentence for students to respond. ${ }^{46}$ After the teacher has finished asking questions, the following student must give a response and give a similar question to the student beside him, while students who have or haven't had a turn can write what they hear. This pattern can be in the form of questions and answers that take place between students and students as well as students and teachers with the content values of character education and multicultural education.

The fifth is gesture. This technique is given so that students can express an activity verbally. In this case, the material presented is in the form of verbs with the prefixes. Movement of activity is demonstrated in front of the class, such as smiling to others,

\footnotetext{
${ }^{45}$ For example: Teacher: Take a look at this picture, what typically does this person do? Student: A Firefighter; Teacher: What does he do?; Student: Help people; Student: Helps put out fires; Student: Rescues people who are on fire; Teacher: Definitely, right. He helps people who are experiencing a disaster.

${ }^{46}$ For example: Teacher: I want to go to Banjarmasin for a holiday, I will go on a religious tour, how about you?; Student 1: I want to go to a vacation and place of worship. I will visit the temple, how about you?; Student 2: I want to go to the village. I will visit my grandma's village, how about you?; Student 3: I want to go to Bali for vacation and I will celebrate Christmas with my cousin, how about you?
} 
demonstrating courtesy, behaving kindly, respecting parents, and various other activities related to the values of character education and multicultural education. Movement can be demonstrated by one student in turn or directly led by the teacher, then followed by a question sentence: "what am I doing?"Sentences and vocabulary can be adjusted according to needs.

The seventh is technique practice patterns. This technique is in the form of repeating verbal sentence patterns in certain forms as instructed by the teacher. This pattern practice is a form of practice in perfecting specific sentences that are preceded by incomplete questions. ${ }^{47}$ It additionally includes practice patterns such as using conjunctions, inserting a prefix of suffixes, compiling complete and perfect sentences, and completing them.

The eight is group conversation. In this technique, the teacher prepares equipment that is a voice recorder and video recorder for conversation. In one class, the students are divided into groups. Each group was given a simple story title about the values of character education and multicultural education. Before the training begins, students are allowed to confer with their group friends about the theme to be conveyed. In this speaking exercise, the teacher asked students alternately to say words or sentences related to these values; they are joined by another group of students. So that the sentences become a complete story. All conversational activities are recorded so that they can be listened to or watched together again. The teacher goes around from group to group to explain or direct students if they experience difficulties. Then, the teacher plays back the next recording to be discussed again, both regarding the content, sentence patterns, intonation, and so on.

The ninth is role-playing. This technique requires students to be creative in performing a role. The teacher gives a specific role assignment that must be done by students. ${ }^{48}$ In this technique, the teacher starts from the simplest way to the more

\footnotetext{
${ }^{47}$ For example: Mira and I are Betawi, Bobi and I are Muslim, Lina and I love reading, I and Tiara visit the place of worship, Budi and I celebrate Christmas, I and Rita are fasting.

${ }^{48}$ For example the conversation: Anton: Assalamualaikum, teacher! Teacher: Wa'alaikumsalam warahmatullahi wa barakatuh, where do you want to go, Anton? Anton: I want to go to the soccer field, Sir (while reaching out and kissing the teacher's hand) Teacher: Wow, do you have a match today? Anton: That's right, sir. Our team will compete today. Teacher: Be sportif and goodluck. Anton: Yes, sir. Sir, I'll leave first. Teacher: Yes, please. Good luck. And so on. Another example, the teacher gives an assignment: Imagine, if you are a teacher, and Anton as your student, what will students say if they meet the teacher on the road? How polite students should be.
} 
Muqarramah Sulaiman Kurdi, Hj. Mardiah, Musyarrafah S. K, Muhammad Iqbal Ghazali Usman, Taslimurrahman

complicated things that need mastery of intricate patterns with the contents of the values of character education and multicultural education.

The tenth is social expression training. In the form of social behavior when communicating expressed verbally, such as giving respect, expressing admiration, joy, saying goodbye, giving praise, congratulations, giving directions, instructions, and so on. The expression patterns practiced in a series of talks on the situations related to the values of character education and multicultural education. This activity is also called to as an exercise communication daily or basic communication. The teacher asks the students to communicate smoothly in a variety of situations, be it a fictitious or engineered teacher situation, or natural situations, such as in introductory activities, greetings, simple conversations, interviews, telephone conversations, where the values of character education and multicultural education.

The eleventh is the practice field. In this activity students are asked to communicate with other people who are outside the classroom using Indonesian. With this direct interaction, students are expected to be able to make language corrections in various aspects directly. For example, students conduct interviews with security school officers, canteen guards, or people outside the school environment. In this activity the attitude of tolerance and respect for others will grow into valuable experiences for students. These values are an important part of character education and multicultural education.

The twelfth is fairy tales, speeches, rhymes, stories, and poetry. In this activity, students are asked to tell stories, make speeches, meditate, poetry, or tell stories with the contents or values of character education and multicultural education. This activity is a means of training students' courage to speak up. If students always appear brave to speak in front of others, then they will indirectly become more skilled and have greater confidence. In addition, to be asked to make speeches, storytelling, recites and poetry, the teacher can also do simple exercises to increase the courage to speak, such as the teacher giving assignments to students at lower levels such as grades 1 and 2 to talk with others (besides class teachers, principals, higher grade students). Activities by conveying fairy tales, speeches, rhymes, stories, and poems are able to foster communicative values, patriotism, Indonesian unity and pluralism. 
The thirteenth is a description of events and nearby objects. Students are asked to tell an event that they have experienced, for example, related to courtesy, reading activities, helping behavior, or related to tolerance or also to tell about things around. Here students are honed their skills to connect various ideas in their minds to make a pattern in the form of information and a report from their observations. In addition to events that he has experienced, students also can be asked to describe historical events or the experiences of others. This is one way to foster the value of social care and care for the environment, but it can also foster the value of honesty, tolerance, pluralism, inclusivism, and curiosity.

The fourteenth is discussion. In this activity, students are asked to discuss a variety of exciting and well-liked topics whose content includes the values of character education and multicultural education, for example regarding patriotism, nationalism, customs, manners, courtesy, courtesy, association, and reading fondness. The goal is that students can find a variety of information and be able to conclude the information into a concrete discourse. Each student is trained to describe or develop ideas that are on his mind. The teacher guides by posing the questions first. The value of tolerance, pluralism, curiosity, and Indonesian unity will grow through this activity.

The teacher ${ }^{49}$ can use more than one strategy in honing students' speaking skills with the content of the values of character education and multicultural education. Actually, all the exercises and techniques used are aimed at honing all aspects of students' verbal language, which includes vocabulary selected according to the purpose of the message to be conveyed, grammar, pronunciation, and more importantly is the content and meaning of the message identified and clearly, the contents of the values of character education and multicultural education can be absorbed by students directly.

${ }^{49}$ Important points that need to be considered by the teacher when conducting speaking exercises are: (a) Teachers do exercises with students intensely. Have a schedule and set the time for training activities; (b) In the discussion exercise between the teacher and students, students' answers that are in the form of imperfect sentences, such as yes and no, should be followed by occasional teachers giving examples of perfect sentence answers and students are asked to imitate them; (c) Question and answer exercises can be done by groups with groups before the teacher asks questions to each group, then questions and answers can be done between groups and groups, and finally between a student and other students; (d) Teachers are strictly forbidden to correct students' mistakes when speaking suddenly; (c) When students are talking, teachers are strictly forbidden to cut or stop the conversation. Because it will cause fear for students which results in students not daring to speak; (e) The teacher should write sentences clearly on the board, especially when the pronunciation practice is vocal closed. 
Muqarramah Sulaiman Kurdi, Hj. Mardiah, Musyarrafah S. K, Muhammad Iqbal Ghazali Usman, Taslimurrahman

\section{How to Test and Evaluate the Speaking Skills of Students with Content Values Character Education and Multicultural Education}

After carrying out various activities to improve students 'speaking skills with the content of character education and multicultural education, teachers should evaluate to determine the level of students' speaking skills. This evaluation can be informed of a speaking skills test with the content of character education and multicultural education. Similar to the nature of the form of the learning process aspects of speaking skills, the test of speaking skills also has the same nature, namely: speaking tests conducted in a controlled manner and tests speaking conducted independently. ${ }^{50}$ In the process of speaking tests carried out in a controlled manner, it can take the form of telling a picture and retelling a story that has been told before or that has been read by students verbally. Whereas in speaking tests conducted freely, students have the freedom to determine their own problems to be discussed. The test and evaluation are conducted through several activities, such as short stories, recounted, free storytelling, reading speech/poetry/news.

\section{CONCLUSION}

Learning models are carried out by analyzing student characteristics, setting learning objectives, selecting media, learning methods, and teaching materials, utilizing teaching materials, involving students in learning activities, evaluating, and revising learning programs. Content of character education that can be used as teaching material includes introducing polite words to children from a young age, being aware of public places, respect, and sensitivity, mastering essential words in life, examples of polite behavior, and correcting actions. Meanwhile, the teacher can apply the multicultural education content as learning materials. Inside the material consist of learning more about various backgrounds of students in the class, such as regional origins and family chains, various types of collection books in the school reading room, cultural festivals in class, food fairs in class to celebrate different dishes from the whole family, a presentation project for students on Indonesian culture or countries in the world, the personal topic of hosting cultural days from various backgrounds. This finding implies that teachers and prospective teachers in the madrasah ibtidaiyah teacher education programs in Indonesia

${ }^{50}$ Soenardi Djiwandono, Tes Bahasa dalam Pengajaran. (Bandung: Penerbit ITB, 1996), 69. 
need to be able to develop superficial educational knowledge and sciences to develop multiculturalism and universal values used in the teaching-learning process.

Understanding will merely be obtained if the learning process is implemented in communication activities, collaboration activities, and critical thinking activities about these values. The teachers need to discuss the learning process with a variety of methods, student learning styles, as well as developing a material with a load of plurality values and other noble values. Character education and multicultural education will succeed if it has been merely introduced to students early on, and the multicultural values and values in character education should be strengthened for years in elementary school. It is significant for students to be given knowledge of values to improve their knowledge, social skills, and enlightened attitudes that naturally fit these values in the classroom

\section{REFERENCES}

Agustin, Ratna. "Penerapan Model Pembelajaran Tipe Team Games Tournament (TGT) Untuk Meningkatkan Keterampilan Berbicara Siswa Kelas V SDN 2 Cerme Pace Nganjuk Tahun Pelajaran 2018." SASTRANESIA: Jurnal Program Studi Pendidikan Bahasa Dan Sastra Indonesia 6, no. 3 (October 1, 2019): 46-55. https://doi.org/10.32682/sastranesia.v6i3.1290.

Amirin, Tatang. M. Implementasi pendekatan pendidikan multikultural kontekstual berbasis kearifan lokal di Indonesia. Jurnal pembangunan pendidikan: Fondasi dan aplikasi, 1, no. 1, (June, 2012): 1-16. https://doi.org/10.21831/jppfa.v1i1.1047.

Anggraini, Ayu Dewi Citra, Ika Ratih Sulistiani, and Devi Wahyu Ertanti. "Strategi Pembelajaran Akidah Akhlak Di MI Sunan Kalijogo Karangbesuki Malang." JPMI: Jurnal Pendidikan Madrasah Ibtidaiyah 1, no. 2 (July 15, 2019): 44-51, http://riset.unisma.ac.id/index.php/JPMI/article/view/3102

Arifin, Ahmad Hidayatullah. Implementasi Pendidikan Multikulutral dalam Praksis Pendidikan di Indonesia. Jurnal Pembangunan Pendidikan: Fondasi dan Aplikasi, 1, no. 1 (June, 2012): 72-82. https://doi.org/10.21831/jppfa.v1i1.1052.

Arsjad, Maidar G., and Mukti. U.S. Pembinaan Kemampuan Berbicara Bahasa Indonesia. Jakarta : Erlangga, 1988.

Baharun, Hasan, and Robiatul Awwaliyah. "Pendidikan Multikultural Dalam Menanggulangi Narasi Islamisme Di Indonesia." Jurnal Pendidikan Agama Islam (Journal of Islamic Education Studies) 5, no. 2 (November 2, 2017): 224-43. https://doi.org/10.15642/jpai.2017.5.2.224-243.

Baidhawy, Zakiyuddin, Pendidikan Agama Berwawasan Multikultural. Jakarta : Erlangga, 2005.

Broto, A. S. Metodologi Proses Belajar Mengajar Bahasa Indonesia. Sala: Tiga Serangkai 1982. 
Muqarramah Sulaiman Kurdi, Hj. Mardiah, Musyarrafah S. K, Muhammad Iqbal Ghazali Usman, Taslimurrahman

Broto, A. S. Pengajaran Bahasa Indonesia sebagai Bahasa kedua di SD Berdasarkan Pendekatan Linguistik Kontrastif. Jakarta: Bulan Bintang, 1980.

Dalyono, Bambang, and Enny Dwi Lestariningsih. "Implementasi Penguatan Pendidikan Karakter Di Sekolah." Bangun Rekaprima: Majalah Ilmiah Pengembangan Rekayasa, Sosial Dan Humaniora 3, no. 2, Oktober (October 11, 2016): 33-42. https://doi.org/10.32497/bangunrekaprima.v3i2.

David Post, Michael. Representations of Meaning Within Textual Personas: An Analysis of 2008 US Presidential Campaign Speeches. Unpublished Thesis. Magister Program. The University of Birmingham, 2009.

Dhieni, Nurbiana, Lara Fridana, Azizah Muis, and Gusti Yarmi. PAUD4106 - Metode Pengembangan Bahasa. Tangerang Selatan: Universitas Terbuka, 2014.

Ekaningtyas, Dita Puspita. "Peningkatan Keterampilan Berbicara Menggunakan Metode Sosiodrama." Paedagogie 13, no. 2 (November 30, 2018): 71-76. https://doi.org/10.31603/paedagogie.v13i2.2368.

Erviana, Vera Yuli, and Laila Fatmawati. "Urgensi Pendidikan Multikultural Sebagai Wadah Strategis Untuk Menanamkan Karakter Erviana, Vera Yuli, and Laila Fatmawati. "Urgensi Pendidikan Multikultural Sebagai Wadah Strategis Untuk Menanamkan Karakter Toleransi Di Sekolah Dasar." Proceeding of The URECOL, January 21, 2019, 297-302, http://repository.urecol.org/index.php/proceeding/article/view/446.

Fauzan, Umar. "Developing EFL Speaking Materials for the Second Semester Students of STAIN Samarinda," 861-64. Surakarta, Jawa Tengah: Universitas Sebelas Maret, 2014. https://core.ac.uk/reader/43024740.

Fitria, Susi. "Speaking Activities In Young Learners Classroom: The Implementation Of Project-Based Learning Approach." Journal of English and Education 1, no. 2 (2013):

90-102, https://citeseerx.ist.psu.edu/viewdoc/download?doi=10.1.1.1011.9805\&rep=rep1\&t ype=pdf.

Handayani, Yesi, and Taufik Hidayat. "Model Talking Stick Dalam Pembelajaran Berbicara." Literasi : Jurnal Bahasa Dan Sastra Indonesia Serta Pembelajarannya 3, no. 1 (October 11, 2019): 41-50. https://doi.org/10.25157/literasi.v3i1.1997.

Hermawan, Acep, Metodologi Pembelajaran Bahasa Arab. Cet. 1. Bandung: PT Remaja Rosdakarya, 2011.

Ibrahim, Ahmad Abdullahi. "Comparative Analysis Between System Approach, Kemp, And ASSURE Instructional Design Models." International Journal of Education and Research 3, no. 12 (2015): 261-70, http://www.ijern.com/journal/2015/December2015/20.pdf.

Judiani, Sri. "Implementasi Pendidikan Karakter di Sekolah Dasar Melalui Penguatan Pelaksanaan Kurikulum." Jurnal Pendidikan dan Kebudayaan 16, no. 9 (October 10, 2010): 280-89. https://doi.org/10.24832/jpnk.v16i9.519.

Karmila, Nita, and Rini Sri Indriani. "Nilai-Nilai Pendidikan Karakter Pada Materi Ajar Pendidikan Lingkungan Hidup Untuk Sekolah Dasar/ Madrasah Ibtidaiyah Kelas II." 
Jurnal Pendidikan Dan Pengajaran Guru Sekolah Dasar (JPPGuseda) 2, no. 1 (March 11, 2019): 26-29. https://doi.org/10.33751/jppguseda.v2i1.991.

Khoiriyah, Khoiriyah, and Angraeny Unidia Rachman. "Bercakap-cakap sebagai Metode Peningkatan Kemampuan Berbicara Anak." JECCE (Journal of Early Childhood Care and Education) 2, no. 1 (March 17, 2019): 38-54. https://doi.org/10.26555/jecce.v2i1.567.

Kurdi, Muqarramah Sulaiman. "Madrasah Ibtidaiyah dalam Pandangan Dunia: Isu-Isu Kontemporer dan Tren dalam Pendidikan." Al Ibtida: Jurnal Pendidikan Guru MI 5, no. 2 (October 31, 2018): 231-48. https://doi.org/10.24235/al.ibtida.snj.v5i2.3194.

Kurdi, Musyarrafah Sulaiman. "Evaluasi Implementasi Desain Pendidikan Karakter Berbasis Pendekatan Humanistik." Elementary: Jurnal Ilmiah Pendidikan Dasar 4, no. 2 (November 27, 2018): 125-38, https://ejournal.metrouniv.ac.id/index.php/elementary/article/view/1243.

Ma'arif, Muhammad Ahyar, and Abdul Hamid. "Pendidikan Karakter Berbasis Pendidikan Islam." An-Nisa' 11, no. 1 (February 6, 2019). https://doi.org/10.35719/ansa.v11i1.759.

Minister of Education and Culture (MOEC), "Kebijakan Penguatan Pendidikan Karakter", 19 July 2019, https://cerdasberkarakter.kemdikbud.go.id/tentang-ppk/.

Muhyiddin, Muhammad, Ikha Ikha Listyarini, and Henry Januar Saputra. "Keefektifan Model Role Playing Berbantu Video Animasi Terhadap Kemampuan Berbicara Siswa Kelas V SD Negeri 01 Terban Kudus." Jurnal Basicedu 3, no. 2 (August 11, 2019): 564-71. https://doi.org/10.31004/basicedu.v3i2.40.

Muliadi, Erlan. "Urgensi Pembelajaran Pendidikan Agama Islam Berbasis Multikultural Di Sekolah." Jurnal Pendidikan Islam 1, no. 1 (2012): 55-68. https://doi.org/10.14421/jpi.2011.11.55-68.

Muqarrahmah, Muqarramah. "Student Centered Learning Approaches; Learning Design Aqidah Morals For Government Elementary School." Tarbiyah: Jurnal Ilmiah Kependidikan 5, no. 2 (February 7, 2017). https://doi.org/10.18592/tarbiyah.v5i2.982.

Musyarafah, Musyarafah. "Development of English Teaching Materials Charged Based Character Education Using Interactive Multimedia Macromediaflash (Case Study Course Learning English Teacher Education Department Madrasah)." Tarbiy: Jurnal Ilmiah Kependidikan 5, no. 2 (February 7, 2017). https://doi.org/10.18592/tarbiyah.v5i2.983.

Ngadiyono, Ngadiyono, and Sukidjo Sukidjo. "Implementasi Pendidikan Karakter Di Madrasah Ibtidaiyah." Harmoni Sosial: Jurnal Pendidikan IPS 6, no. 1 (March 24, 2019): 86-99. https://doi.org/10.21831/hsjpi.v6i1.15397.

Nurgiyantoro, Burhan. Teori Pengkajian Sastra. Yogyakarta: Gadjah Mada University Press, 2007.

Nurhayati, Dwi Astuti Wahyu. "Using Local Drama in Writing and Speaking: EFL Learners' Creative Expression." Journal of English Language Teaching and Linguistics 1, no. 1 (April 17, 2016): 51-77. https://doi.org/10.21462/jeltl.v1i1.13.

Pribadi, Benny A. Model Desain Sistem Pembelajaran. Jakarta: Dian Rakyat, 2009. 
Muqarramah Sulaiman Kurdi, Hj. Mardiah, Musyarrafah S. K, Muhammad Iqbal Ghazali Usman, Taslimurrahman

Putra, Purniadi. "Pendidikan Karakter Berbasis Etnopedagogi Di Madrasah Ibtidaiyah Negeri Kabupaten Sambas Kalimantan Barat." Disertasi, Universitas Islam Negeri (UIN) Antasari Banjarmasin, 2019. http://idr.uin-antasari.ac.id/11242/.

Rahardi, R. Kunjana. Bahasa Kaya, Bahasa Berwibawa: Bahasa Indonesia Dalam Dinamika Konteks Ekstrabahasa. Yogyakarta: Andi Offset, 2006.

Rahardi, R. Kunjana. Dimensi-Dimensi Kebahasaan: Aneka Masalah Bahasa Indonesia Terkini. Jakarta: Erlangga, 2006.

Rahayu, Minto. Bahasa Indonesia di Perguruan Tinggi. Jakarta: Grasindo, 2007.

Rosyada, Dede. "Pendidikan Multikultural Di Indonesia Sebuah Pandangan Konsepsional." Sosio-Didaktika: Social Science Education Journal 1, no. 1 (June 29, 2014): 1-12, https://doi.org/10.15408/sd.v1i1.1200.

Russell, James D., and And Others. "Improving Technology Implementation in Grades 5-12 with the ASSURE Model." T.H.E. Journal 21, no. 9 (1994): 66-70, , https://eric.ed.gov/?id=EJ481965.

Simbolon, Marlina Eliyanti S. S. Tuturan dalam Pembelajaran Berbicara Dengan Metode Reciprocal Teaching. Jakarta: Media Sahabat Cendekia, 2019.

Smaldino, Sharon E, Deborah L Lowther, Clif Mims, James D Russell. Instructional Technology and Media for Learning. Upper Saddle River, N.J. : Pearson/Merrill/Prentice Hall, 2005.

Soenardi, Djiwandono. Tes Bahasa dalam Pengajaran. Bandung: Penerbit ITB, 1996.

Soeparno, Soeparno. "Penerapan Teori Tagmemik, Dalam Pengajaran Bahasa Indonesia." Jurnal Cakrawala Pendidikan 1, no. 1 (1988). https://doi.org/10.21831/cp.v1i1.7437.

Stevens, Florence. "Activities to Promote Learning and Communication in the Second Language Classroom." TESOL Quarterly 17, no. 2 (1983): 259-72. https://doi.org/10.2307/3586653.

Sugeng, Bambang. "A Learning Strategy Profile of Indonesian Elementary School Students." RELC Journal 28, no. 2 (December 1, 1997): 82-106. https://doi.org/10.1177/003368829702800205.

Suharto, G. Suharto G. "Pendidikan Bahasa Dalam Konteks Pendidikan Nasional." Jurnal Cakrawala Pendidikan 3, no. 3 (1997). https://doi.org/10.21831/cp.v3i3.9107

Syafruddin, Syafruddin, Masyhuri Masyhuri, and Suud Suud. "Urgensi Pendidikan Multikultural Untuk Mencegah Faham Radikalisme Pada Siswa SMA Dan MA Di Kecamatan Dompu." Jurnal Pendidikan Dan Pengabdian Masyarakat 2, no. 1 (January 23,

2019). https://jurnalfkip.unram.ac.id/index.php/JPPM/article/view/1009.

Tarigan, Henry Guntur. "Berbicara Sebagai Suatu Keterampilan Berbahasa." Bandung: Angkasa, 2008.

Trudell, Barbara, and Benjamin Piper. "Whatever the Law Says: Language Policy Implementation and Early-Grade Literacy Achievement in Kenya." Current Issues in Language Planning 15, no. 1 (January 2, 2014): 4-21. https://doi.org/10.1080/14664208.2013.856985. 
Speaking Activities in Madrasah Ibtidaiyah...

82 Al-Bidayah, Volume 12, Number 1, June 2020 